\title{
Gene expression analysis in response to combined salt and boron (B) stresses in a tolerant maize landrace
}

\author{
Wilson Huanca-Mamani ${ }^{1}{ }^{*}$, Marcelo Vargas Ortiz $^{1}$, Steffany Cárdenas-Ninasivincha ${ }^{1}$, Gerardo Acosta- \\ Garcia $^{3}$, Elizabeth Bastías ${ }^{2}$
}

${ }^{1}$ Laboratorio de Biología Molecular de Plantas, Depto. Producción Agrícola. Fac. Cs. Agronómicas, Universidad de Tarapacá, Chile

${ }^{2}$ Laboratorio de Fisiología Vegetal, Depto. Producción Agrícola. Fac. Cs. Agronómicas. Universidad de Tarapacá, Chile

${ }^{3}$ Departamento de Ingeniería Bioquímica, Instituto Tecnológico de Celaya, Av. Tecnológico y A. García Cubas S/N, Col. Alfredo V. Bonfil C.P. 38010, Celaya, Gto. México

*Corresponding author: whuanca@uta.cl

\begin{abstract}
To understand the molecular stress response in maize plants to high salt and boron (B) stress, we focused on the transcript accumulation of six stress-related genes in Lluteño maize, a sweet corn landrace from the Lluta valley (northern Chile). This landrace is tolerant to salt and B stress. A randomized complete block design with four replications was used. Seedlings of Lluteño maize and maize hybrid B73 were exposed to $150 \mathrm{mM} \mathrm{NaCl}$ and $20 \mathrm{ppm} \mathrm{B}$ in nutrient solution for 120 hrs, then root and leaf samples were collected and $\mathrm{Na}^{+}$and $\mathrm{B}$ content were determined. Transcript accumulation of three salt stress-related genes SOS1, NHX2 and HKT1 and three B stress-related genes BOR1, BOR2 and PIP1;2 were determined in roots and leaves of Lluteño maize using RT-PCR and real-time PCR at 3 and $96 \mathrm{~h}$ after treatment with $150 \mathrm{mM} \mathrm{NaCl}$ and/or $20 \mathrm{ppm} \mathrm{B}$. The results indicated that combined salt and B stress caused changes in physiological parameters. The damage was more severe in B73 than in Lluteño maize, confirming that this landrace behaves as a plant tolerant to these stresses. Regulation of stress-related genes under combined stress was different under individual stresses. The ability of Lluteño maize to survive and thrive in soil with high salinity and $B$ concentration is probably based on a decrease in membrane water permeability, preventing salt and $B$ uptake from the roots through down-regulation of $B O R 1, B O R 2$ transporters and PIP1;2 aquaporin. The increased water transport is mediated by the upregulation of the PIP1;2 in leaves, allowing cellular water conservation, and the retrieval of $\mathrm{Na}^{+}$from xylem through up-regulation of HKT1;1 transporters in roots and leaves.
\end{abstract}

Keywords: Salt tolerance, boron tolerance, Lluteño maize, SOS1, NHX2, HKT1;1, BOR1, BOR2, PIP1;2.

Abbreviations: BOR_boric acid/borate transporters; HKT_high-affinity $\mathrm{K}^{+}$transporter; KIRC_K $\mathrm{K}^{+}$inward-rectifying channel; KORC_K $\mathrm{K}^{+}$ outward-rectifying channel; $\mathrm{NHX1 \_} \mathrm{Na}^{+} / \mathrm{H}^{+}$antiporter 1; PIP_plasma membrane intrinsic protein; SOS1_salt overly sensitive 1.

\section{Introduction}

Crops under field conditions are routinely subjected to a combination of different abiotic stresses. Soil salinity and boron (B) toxicity are both significant constraints to crop production in several arid and semiarid regions around the world, including South Australia, Iraq, Turkey, California and northern Chile (Tanaka and Fujiwara, 2008). Simultaneous stress induced by $B$ toxicity and salinity can occur either when plants are irrigated with water containing a high level of B and salts (Camacho-Cristobal et al., 2008; Nable et al., 1997) or if plants are grown in soils with natural presence of high concentrations of salts and B. The Lluta valley, located in a hyper-arid region of northern Chile, naturally has agricultural soil and irrigation water with high concentrations of salts and boron, which fluctuate between 2.2-5.9 $\mathrm{dSm}^{-1}$ and 10-29 ppm in soil and irrigation water, respectively (Torres and Acevedo, 2008), strongly limiting crop production in this valley (Tapia and Vega, 2009).

One of the crops adapted to these drastic conditions is a sweet corn landrace called Lluteño maize (Zea mays L. cultivar amylacea), which has evolved to thrive in hyper-arid habitats such as the Lluta valley. This landrace possesses remarkable tolerance to salinity and high $\mathrm{B}$ content as a consequence of continuous selection by farmers in this valley for generations (Bastías et al., 2004).

Under hydroponic conditions Lluteño maize is able to tolerate simultaneously $430 \mathrm{mM} \mathrm{NaCl}$ and $40 \mathrm{ppm} \mathrm{B}$ without exhibiting symptoms of toxicity for over 20 days of treatment. It accumulates high levels of $\mathrm{Na}^{+}$in roots without the occurrence of severe alterations in the radical tissue, besides avoiding its transport and accumulation in aerial 
parts that prevents damage to the photosynthetic apparatus, while $B$ is translocated to leaves (Bastías et al. 2004). B availability in Lluteño maize mitigates in part the negative effect of salinity. This landrace is more salt-tolerant compared to many commercial genotypes such as Pioneer hybrid 3578, G2 and SRO73 (Bastias et al. 2004). These abilities confer Lluteño maize a good target to study the mechanisms of tolerance to combined stress by salinity and B.

Plants have evolved sophisticated defense mechanisms to respond to stress that increase tolerance to adverse conditions by controlling the different physiological and biochemical process (Rampino et al., 2006). Manipulation of gene expression has been a challenging approach and an important tool to improve crop response to stresses (Yousfi et al., 2016). Numerous studies have focused on the response mechanisms of plants to a single stress treatment. However, field crops and other plants are routinely subjected to a combination of different stresses (Mittler, 2006). In recent decades, several agronomic and physiological studies have focused on the responses of plants to different combinations of environmental stresses (Suzuki et al., 2014 and references therein). These studies have revealed that the response of plants to combination of different abiotic stresses cannot be directly extrapolated from the response of plants to each stress applied individually (Suzuki et al., 2014; Colmenero-Flores, 2014).

In arid or semi-arid regions where the effect of salinity in agricultural lands is aggravated by B toxicity, it is necessary to study the response of plants to various stresses imposed simultaneously. Plants respond to salinity or B toxicity through several physiological, metabolic and molecular mechanisms. These mechanisms are interconnected and finely regulated, allowing plants to respond specifically, to adapt and thrive to these environments.

The salinity stress signal is perceived by receptors present in the plasma membrane of cells. This signal activates various ion pumps present in plasma and vacuolar membranes. The $\mathrm{Na}^{+}$ions enter the cell via different channels including KIRC, KORC or by carriers such as HKT, which can be translocated out of the cell or into the vacuole by the action of a plasma membrane $\mathrm{Na}^{+} / \mathrm{H}^{+}$antiporter (SOS1) or a vacuolar $\mathrm{Na}^{+} / \mathrm{H}^{+}$exchanger $(\mathrm{NHX})$ and $\mathrm{H}^{+} / \mathrm{Ca}^{+}$ antiporter (CAX1). The $\mathrm{Na}^{+}$extrusion from plant cells is powered by the electrochemical gradient generated by $\mathrm{H}^{+}$ATPases, which permits the $\mathrm{Na}^{+} / \mathrm{H}^{+}$antiporter to couple the passive movement of $\mathrm{H}^{+}$inside along the electrochemical gradient and to extrude $\mathrm{Na}^{+}$out of the cytosol (Tuteja, 2007; Munns and Tester, 2008; Hanin et al., 2016).

Under conditions of adequate or excessive B availability, boric acid adsorption by roots is mediated by a passive process that involves mostly $B$ diffusion across the lipid bilayer. Boron uptake may be mediated by NIP and PIP proteins, members of the major intrinsic protein (MIP) channel family that function as a channel for water and small uncharged molecules and are expressed in epidermis, cortex and endodermis. They import boric acid into epidermal, cortical and endodermal cells (Polsia et al., 2016). In the stele, the boric acid/borate transporters (BORs) export boric acid/borate from stellar cells into the xylem (xylem loading) (Takano et al., 2005; Takano et al., 2006; Maurel et al., 2008; Miwa et al., 2013). Boron can be transported through the symplastic pathway, flow from cell to cell by plasmodesmata and the apoplastic pathway, which is an extracellular pathway provided by the continuous matrix of cell walls (Camacho-Cristobal et al., 2008; Tanaka and Fujiwara, 2008; Polsia et al., 2016).

There are few studies available on the combined effect of $\mathrm{NaCl}$ stress and $\mathrm{B}$ toxicity in plants and even very few researches have focused on their effects on a tolerant maize landrace. To understand the stress response at molecular level involved in combined stress induced by high concentration of $\mathrm{NaCl}$ and $\mathrm{B}$ in Lluteño maize, we focused on the activity of three salt stress genes related to $\mathrm{Na}^{+}$efflux from root to soil (SOS1), the sequestration of $\mathrm{Na}^{+}$in vacuoles (NHX2) and the retrieval of $\mathrm{Na}^{+}$from xylem (HKT1); and three $B$ stress genes related to its transport mediated by transporters (BOR1 and BOR2) and by channels (PIP1;2).

\section{Results}

\section{Differential responses of Lluteño and B73 maize to salinity} and boron stress.

After 8 days of combined stress induced by $150 \mathrm{mM} \mathrm{NaCl}$ and $20 \mathrm{ppm} \mathrm{B}$, Lluteño maize did not show morphological responses to these stresses compared to control plants (Figure-1A). In contrast, hybrid B73 developed the typical leaf symptoms, yellow with necrotic lesions at the tip during the first days, and after 8 days all leaves were drastically affected (Figure 1A).

To quantify the $\mathrm{Na}^{+}$and $\mathrm{B}$ distribution in both maize genotypes under stress, the amounts of these ions were measured in roots and leaves $120 \mathrm{~h}$ after combined stress induction. The $\mathrm{Na}^{+}$and $\mathrm{B}$ content in leaves and roots were increased significantly. The $\mathrm{Na}^{+}$was preferentially accumulated in roots; however, this accumulation was significantly different in Lluteño maize, in which leaf $\mathrm{Na}^{+}$ content was almost half of roots, while in the hybrid, $\mathrm{Na}^{+}$ was similar in both tissues (Figure 1B). B content was not different between roots and leaves in both maize varieties; however, Lluteño maize accumulated around of half of the total B content found in the hybrid maize (Figure 1C).

\section{Stress gene activity in Lluteño maize}

To examine the activity of the SOS1, NHX2, HKT1;1, BOR1, $B O R 2$ and PIP1;2 genes in roots and leaves, samples of Lluteño maize under stress were induced by high concentration of $\mathrm{NaCl}$ and/or B at 3 and $96 \mathrm{~h}$. The expression pattern of these genes was analyzed by semi-quantitative RT-PCR and real time PCR (RT-qPCR).

The Lluteño plants under $\mathrm{NaCl}$ and/or $\mathrm{B}$ stress were evaluated by semi-quantitative RT-PCR analysis. The control reactions were carried out using activity of the ACT1 gene. To complement this and provide a more quantitative assessment of expression of these genes during combined stress they were evaluated by RT-qPCR analysis. Standard curves (2-fold dilution) were generated for each transcript. All analyzed genes had PCR efficiencies in the $90-105 \%$ range. Melting curves were generated and no double melting peaks were observed for any of the genes (data not shown), indicating pure PCR products. The transcriptional activity of each gene was normalized with the reference gene $C U L$ and compared to the unstressed control sample. 
Salt and B stress genes were differentially expressed in response to $\mathrm{NaCl}$ and/or $\mathrm{B}$ treatments.

In Lluteño maize roots exposed to $150 \mathrm{mM} \mathrm{NaCl}$, the activity of SOS1 was increased at least $3 \mathrm{~h}$ after stress (Figure 2). In the presence of $20 \mathrm{ppm} \mathrm{B}$, the SOS1 activity was not altered (Figure 2), and under combined stress its activity decreased significantly over time (Figures 2 and 3 ). In leaf tissue, SOS1 started to increase its activity within $3 \mathrm{~h}$ and evidently at $96 \mathrm{~h}$ (Figure 2). Under B or combined stress its activity was not significantly altered (Figures 2 and 3 ).

The NHX2 activity in roots increased slightly within $3 \mathrm{~h}$ of salinity stress and was not altered under B stress (Figure 2). Under combined stress its activity was not significantly changed (Figures 2 and 3). The NHX2 expression was not altered in any treatment in leaf tissue (Figures 2 and 3 ).

The HKT1;1 expression was not obviously altered in Lluteño maize roots under either $\mathrm{NaCl}$ or $\mathrm{B}$ stress (Figure 2). In contrast, under combined stress its activity increased significantly over time (Figures 2 and 3). The HKT1;1 activity in leaves was increased within $3 \mathrm{~h}$ and constantly maintained up to $96 \mathrm{~h}$ under salt stress. However, its activity did not change over time under B stress (Figure 2). Under combined stress, the HKT1;1 activity was increased significantly within $3 \mathrm{~h}$ (Figure 2 and 3 ).

In the B stress-related genes evaluated in Lluteño maize, the activity of $B O R 1$ and $B O R 2$ was not altered by $\mathrm{NaCl}$ or $\mathrm{B}$ in roots and leaves. However, its activity was decreased significantly over time in both tissues under the combined stresses (Figures 2 and 3).

The PIP1;2 activity in roots was not altered under saline and B stress. A double PCR product was detected at $96 \mathrm{~h}$ under salt stress. These products were detected in the three biological replicates analyzed. An alternative splicing is probably induced for PIP1;2 by salt stress (Figure 2). PIP1;2 expression in roots was significantly decreased at $96 \mathrm{~h}$ under combined stress (Figures 2 and 3 ). Its activity in leaves was increased in all treatments (Figures 2 and 3 ).

\section{Discussion}

Landraces represent an important part of the plant diversity adapted under limiting environmental conditions (Moles et al., 2016). Evaluation of germination comparing several northern Chilean and domestic U.S.A. germplasms under high B concentration showed that the Chilean germplasms are better adapted to this stress (Bañuelos et al., 1999). Recently, Ruiz et al. (2016) showed that northern highland quinoa (Chenopodium quinoa Willd.) landraces were better adapted to salinity than those from the central zone. Since Chilean northern soils have high content of salt and B, their germplasms may be better adapted to these two stresses.

Studying abiotic stress individually is valuable, but it can be misleading because plant responses to combinations of abiotic stress are different from those of each individual stress (Suzuki et al., 2014; Colmenero-Flores and Rosales, 2014). In this study, we compared the expression pattern of some stress-related genes in Lluteño maize, a landrace adapted to soil and water with high salinity and B concentration, in response to salt, B and combined stresses. The content of $\mathrm{Na}^{+}$and $B$ in leaves and roots increased dramatically with combined $\mathrm{NaCl}$ and $\mathrm{B}$ application, albeit with significant differences between hybrid and Lluteño maize genotypes. Leaves of B73 showed toxic symptoms, while Lluteño maize did not show any issue (Figure 1A). In Lluteño maize under these stresses the $\mathrm{Na}^{+}$content of roots was almost twice than leaves. However, in B73 the concentration of $\mathrm{Na}^{+}$was almost the same in these two tissues. In addition, the total amount of $\mathrm{Na}^{+}$(leaves and roots) was greater in B73 than in Lluteño maize. Boron was accumulated at similar concentrations in leaves and roots of both germplasms. However, the total amount of B (leaves and roots) in Lluteño maize was almost half of B73 (Figure $1 B)$. These results suggest that under combined stresses, Lluteño maize is able to restrict $\mathrm{Na}^{+}$movement to the aerial tissues and to decrease the uptake of $B$ entering the roots.

Lower $\mathrm{Na}^{+}$accumulation in leaves in relation to roots was also found in some tolerant plants in response to salinity (Hajibagheri et al., 1987; Fortmeier and Schubert, 1995; Sun et al., 2010; Rahman et al., 2016) and in the combination of salinity with a second stress (Rivero et al., 2104; Mohamed et al., 2016). The lower total $\mathrm{Na}^{+}$accumulation in Lluteño in comparison to B73 is in accordance with salt tolerant glycophytes accumulating less salt than sensitive ones (Tester and Davenport, 2003). It has been proposed that under combined salt and B stress, a decrease of B concentration in the presence of salinity might be due to salinity-induced stomatal resistance, and since entry of $B$ is in part due to passive processes and influence of transpiration rate (Eraslan et al., 2007; Mohamed et al., 2016). In Lluteño maize, this mechanism could be involved in the reduction of the $B$ uptake in roots and its subsequent translocation to the leaves.

We evaluated the expression of 6 genes known to be involved in different mechanisms of either salt or B tolerance at 3 and $96 \mathrm{~h}$ after stress, using RT-PCR and RTqPCR analyses. We selected these two time points because maize plants under salt shock showed better transcriptional response at $3 \mathrm{~h}$ (Wang et al., 2003) and around $72 \mathrm{~h}$ after salt stress maize seedlings were able to recover from the osmotic effect (Rodríguez et al., 1997).

The Salt Overly Sensitive 1 (SOS1) gene encodes a plasma membrane $\mathrm{Na}^{+} / \mathrm{H}^{+}$antiporter, which mediates $\mathrm{Na}^{+}$efflux at the root surface and regulates long-distance $\mathrm{Na}^{+}$transport from root to shoot (Zhu, 2003). The SOS1 was up-regulated in Lluteño roots and leaves in the presence of $\mathrm{NaCl}$. Similar results have been reported in salt tolerant genotypes of wheat (Sathee et al., 2015), Medicago (Liu et al., 2015) and alfalfa (Sandhu et al., 2017). However, they did not report significant differences under $\mathrm{B}$ or combined stress compared to control plants. These results suggest that under saline stress, $\mathrm{Na}^{+}$exclusion is important in providing tolerance. However, under combined stress the exclusion could be mediated by other genes, or perhaps the basal expression level of SOS1 in Lluteño maize is enough to cope with the simultaneous stress induced by $100 \mathrm{mM} \mathrm{NaCl}$ and $20 \mathrm{ppm} \mathrm{B}$. $\mathrm{Na}^{+}$sequestration into the vacuole partially depends on the expression and activity of $\mathrm{Na}^{+} / \mathrm{H}^{+}$antiporters (NHX) (Apse et al., 1999). In Arabidopsis, NHX1 and NHX2 isoforms are present in the vacuolar membrane and partition $\mathrm{Na}^{+}$into the vacuole, protecting the cytosol from its toxic effects (Barragan et al., 2012). In this study, the activity of NHX1 and its expression was slightly increased in roots under salt or B. However, under combined stress it was not altered. In leaves its activity did not change under any conditions. Similar results were observed in Suaeda glauca, a succulent halophyte, exposed to $300 \mathrm{mM} \mathrm{NaCl}$ (Jin et al., 2016); some 
Table 1. Transcripts selected for RT-PCR and RT-qPCR analysis. Gene name, GenBank accession numbers, primer sequences and product size.

\begin{tabular}{|c|c|c|c|}
\hline Gene name & GenBank accession number & Primer sequence (5'- 3'; Forward / Reverse) & Product size (bp) \\
\hline \multirow[t]{2}{*}{ SOS1 } & GRMZM2G067747 & AAGGACTTGGCTTGTCAG & 290 \\
\hline & & TGGCCGAGACATGTTAAC & \\
\hline \multirow[t]{2}{*}{ NHX2 } & GRMZM2G063492 & GGATGAAACACCCCTACT & 320 \\
\hline & & AGAATTCCACTCAGGTCC & \\
\hline \multirow[t]{2}{*}{ PIP1;2 } & NM_001111464.1 & AGGGCCCTCTTCTACATC & 315 \\
\hline & & GTTGATGCCAGTGCCAGTA & \\
\hline \multirow[t]{2}{*}{ HKT1 } & GRMZM2G047616 & CTCGTTGCAGCGGTCTTC & 309 \\
\hline & & AGCAATCTGCCGCCTCTC & \\
\hline \multirow[t]{2}{*}{ BOR1 } & GRMZM2G166159 & TGAATACGAGGAATCACCA & 297 \\
\hline & & AACTTGGATGGCGTCCTAG & \\
\hline \multirow[t]{2}{*}{ BOR2 } & GRMZM2G051753 & CTTCAAGGGAGTTGTCAC & 219 \\
\hline & & ATGCCACATATCGCAGTC & \\
\hline \multirow[t]{2}{*}{ ACT1 } & GRMZM2G126010 & TCCTGACACTGAAGTACC & 286 \\
\hline & & ACACCATCACCTGAATCC & \\
\hline \multirow[t]{2}{*}{ SOS1 } & GRMZM2G067747 & GCTGGATTGGACGTTGATAATC & 140 \\
\hline & & TGCTTCATAACCATCCCTGTG & \\
\hline \multirow[t]{2}{*}{$N H X 2$} & GRMZM2G063492 & GCATTCTTGTGTTCAGCGAG & 139 \\
\hline & & AGAGTCCCAATAGCACCAAAC & \\
\hline \multirow{2}{*}{ PIP1;2 } & NM_001111464.1 & GACATGCCAGTCCGAAGAA & 86 \\
\hline & & CTCTGTCGATTCCTATTCGTCG & \\
\hline \multirow[t]{2}{*}{ HKT1 } & GRMZM2G047616 & CTTGTTAGGAAGAGGATCAGCC & 113 \\
\hline & & AAGGACTTGAAGGACACCATC & \\
\hline \multirow[t]{2}{*}{ BOR1 } & GRMZM2G166159 & ATATGTGCCCTCAAACCCG & 133 \\
\hline & & CGAGGCTATGAATGGAAGAGG & \\
\hline \multirow[t]{2}{*}{ BOR2 } & GRMZM2G051753 & TTCACAGGCTAGTTCGAGTTG & 124 \\
\hline & & GCAACAGTATTCACATCAACGG & \\
\hline \multirow[t]{2}{*}{ CUL } & GRMZM2G166694 & GAAGAGCCGCAAAGTTATGG & 274 \\
\hline & & ATGGTAGAAGTGGACGCACC & \\
\hline
\end{tabular}

In bold, primers used for RTqPCR

A

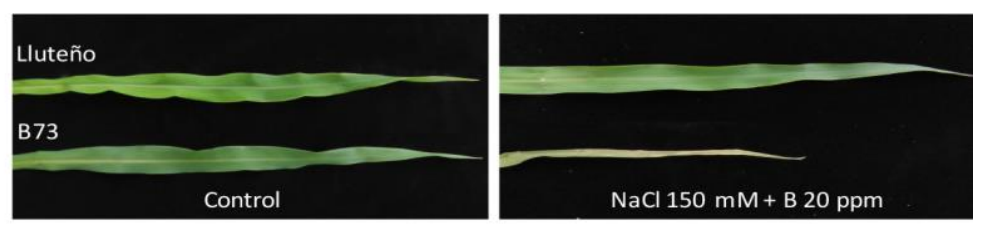

B

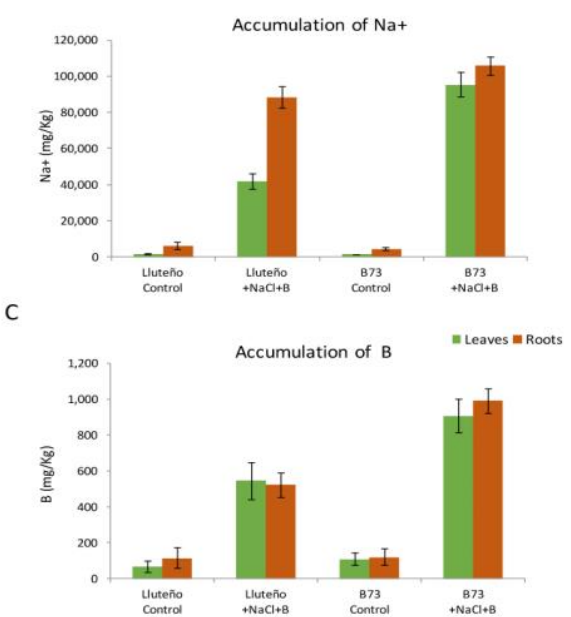

Fig 1. Responses of Lluteño and $B 73$ maize under salinity and B stress. (A) Differential responses of Lluteño and B73 leaves to salinity $(150 \mathrm{mM} \mathrm{NaCl})$ and $B(20 \mathrm{ppm})$ stress after $120 \mathrm{~h}$. (B) $\mathrm{Na}^{+}$accumulation in Lluteño and B73 maize seedlings. (C) B accumulation of Lluteño and hybrid B73 maize seedlings. 


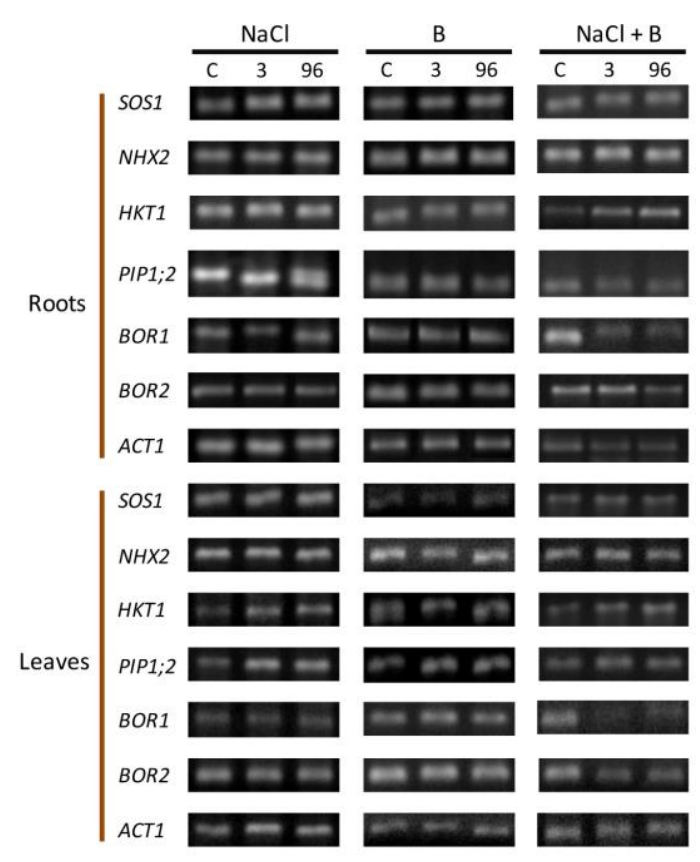

Fig 2. Semi-quantitative RT-PCR analysis of the expression of SOS1, NHX2, HKT1, BOR1, BOR2 and PIP1;2 in Lluteño maize roots and leaves in response to $150 \mathrm{mM} \mathrm{NaCl}$ and $20 \mathrm{ppm} \mathrm{B}$ at 3 and $96 \mathrm{~h}$ after stress. The Actin1 (ACT1) gene was used as internal loading control. C: Control sample; 3 and 96: hours after stress.

\section{A}

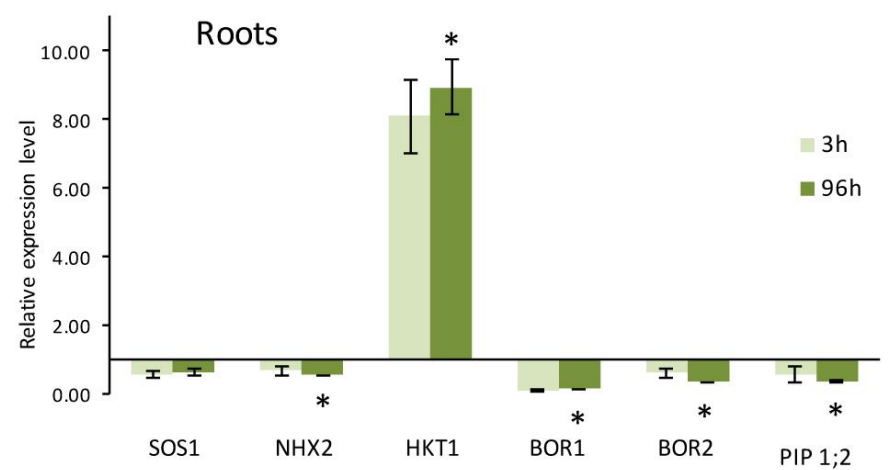

B

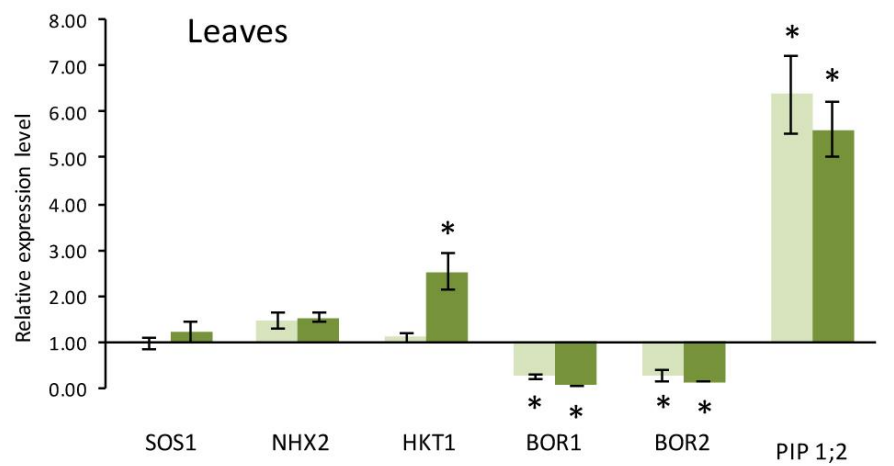

Fig 3. Real-time PCR analysis of the expression of SOS1, NHX2, HKT1, BOR1, BOR2 and PIP1;2 in Lluteño maize in response to 150 $\mathrm{mM} \mathrm{NaCl}$ and $20 \mathrm{ppm} \mathrm{B}$ in roots (A) and leaves (B), at 3 and $96 \mathrm{~h}$ after stress. The relative transcription level was analyzed using the $2^{-\Delta \Delta C t}$ method, and the transcription level at control time was normalized as 1 . The values are presented as average and standard error (SE) of three independent experiments, with three technical replicates. The asterisks represent significant differences in gene expression compared to control. $\left({ }^{*}\right) \mathrm{P} \leq 0.05$. 
salt tolerant alfalfa genotypes did not show differences in the NHX1 or NHX2 expression in leaves or roots under salt stress conditions (Sandhu et al., 2017). Our observations suggest that in salt stressed Lluteño maize, the partition of $\mathrm{Na}^{+}$in root vacuoles is mediated partially by NHX1. However, under a combined stress induced by $100 \mathrm{mM} \mathrm{NaCl}$ and 20 ppm B, the basal expression level of NHX1 is enough to cope with these stresses.

The HKT1 is involved in retrieving $\mathrm{Na}^{+}$from the xylem to the root, maintaining low $\mathrm{Na}^{+}$content in the leaves (Rubio et al., 1995). The activity of the HKT1;1 gene was increased in roots and leaves under salt, while under combined stress it was up-regulated over 8- and 2-fold in roots and leaves, respectively. The HKT1 is highly expressed in tolerant genotypes of alfalfa under salt stress (Sandhu et al., 2017). It has been reported that the maize HKT1;1 gene undergoes alternative splicing in the third exon, producing two isoforms (HKT1;1a and HKT1;1b), which respond differently to salt stress (Ren et al., 2015). In our analysis, the HKT1;1 primers spanned the first and second exon, so we were not able to discriminate between them. In Arabidopsis, AtHKT1;1 is expressed in the vasculature in roots and shoots (Mäser et al., 2002). Our results suggest that under combined stress, the low $\mathrm{Na}^{+}$content observed in Lluteño maize leaves could be mediated by HKT1, probably through retrieving $\mathrm{Na}^{+}$from xylem to roots. Alfalfa genotypes with high HKT1 expression also have higher biomass yield under salinity (Sandhu et al., 2017). Lluteño maize was able to produce $20-25 \mathrm{t} / \mathrm{ha}^{-1}$ biomass (Fuentes and Subiabre, 2009), similar to some hybrid maize genotypes with high yield of grain and dry matter in non-saline soils (Ruiz et al., 2006). The relation between the high HKT1 and high biomass in Lluteño maize should be further studied.

The BOR1 and BOR2 encode efflux $B$ transporters localized in plasma membrane cells facing the stele (Miwa et al., 2013). In Lluteño maize, the BOR1 and BOR2 genes did not change their activity in any tissue under salt or B stress, while under combined stress they were significantly reduced in both tissues. This decrease may prevent the uptake of $B$ into the roots. There are different strategies to overcome $B$ toxicity. In Arabidopsis under high concentration of B, AtBOR1 mRNA accumulation in roots or shoots was not affected, but the BOR1 transporter was degraded by ubiquitination, which prevented $B$ accumulation to a toxic level in plant tissues (Takano et al., 2005; Yoshinari et al., 2012). In barley, the B-tolerant landrace Sahara 3771 contains about four times copies of Bot1, a BOR1 ortholog, which produced more Bot1 transcripts than an intolerant landrace (Sutton et al., 2007). In Lluteño maize, the downregulation of BOR1 and BOR2 would reduce the $B$ uptake into the roots and its subsequent mobilization to aerial parts, producing the lower of total B content observed in this landrace compared to the commercial hybrid (Figure 1C).

Plasma membrane intrinsic proteins (PIPs) are a subfamily of the aquaporins, which are channel proteins that mediate the transport of water and various low molecular weight solutes and response to several environmental stresses (Dordas et al., 2001; Zhu et al., 2005; Maurel et al., 2008; Kumar et al., 2014). Putative protein sequence analysis of the barley aquaporins showed that isoforms HvPIP1;1, HvPIP1;2 and HvPIP2;1 are salt-responsive and possible boron transporters (Hove et al., 2015). The activity of plant aquaporins in response to biotic or abiotic stress is differentially regulated by tissue and/or cultivar variation (Jang et al., 2004, Ouziad et al., 2006; Porcel et al., 2006, Kumar et al., 2014; Hove et al., 2015, Pawlowicz et al., 2017). In our study, the activity of PIP1;2 did not change under B stress in roots, but decreased significantly under salt or combined stress. However, it was accumulated in leaves under salinity, B or combined stresses. Our data agrees with some other studies. Salt stress decreased the expression of $P I P 1 ; 2$ in tomato roots inoculated with mycorrhiza and increased its expression in leaves (Ouziad et al., 2006). In bean plants, the abundance of roots PIP1 proteins was decreased under drought stress, but increased in leaves (Aroca et al., 2006). In contrast, salt stress treatment did not influence the PIP1;2 expression in the aerial part of Arabidopsis, while its activity was significantly increased in roots (Jang et al., 2004). It is possible that the downregulation of plasma membrane PIP1:2 in roots is a regulatory mechanism that reduces the uptake of water from the soil with high salt and B content, thus restricting their subsequent movement and accumulation in aerial parts. Moreover, the PIP1:2 up-regulation in leaves increases cellular water conservation, maintaining a reasonable plant water status under drastic conditions. Further analysis is necessary to determine if these differences in tissue-specific expression are related to different controls of water flow are necessary further analysis.

The behavior of most evaluated genes in Lluteño maize in response to salinity or high B concentration (applied individually) were in accordance with previous reports. However, the response to combined stress was not very similar to the individual stress responses. So, this landrace may have particular pathways to adapt simultaneously to salinity and high B conditions. This is the first report on the activity of a group of stress-related genes in response to combined salt and B stress in a tolerant maize landrace.

\section{Materials and Methods}

\section{Plant growth and stress treatment}

Lluteño maize (Zea mays L. cultivar amylacea) and commercial sweet corn hybrid B73 seeds were germinated in perlite under greenhouse conditions for 14 days. Seedlings were transferred to hydroponic culture with Hoagland's solution, which was renewed every 3 days. After 10 days of acclimatization, seedlings were exposed to four treatments: i) $150 \mathrm{mM} \mathrm{NaCl}$, ii) $20 \mathrm{ppm} \mathrm{B}$, iii) $150 \mathrm{mM} \mathrm{NaCl}$ and $20 \mathrm{ppm} B$ and iv) control plants, which were grown under identical conditions but without added $\mathrm{NaCl}$ or $\mathrm{B}$ during all experiments. Each treatment included four replications, each consisting of 10 maize seedlings. A Randomized Complete Block Design (RCBD) was used, consisting of four treatments. Each treatment comprised of four biological replicates, while each replicate consisted of 10 maize plants. The stressed and control roots and leaves samples for gene expression analysis were collected in three pools of three plants each, at 3 and 96 hours after stress. Since Lluteño maize is a local landrace, there is genetic variability within the population. Therefore, we decided to collect the samples in a pool of three plants per treatment 
per time. The harvested tissues were frozen in liquid nitrogen and immediately stored at $-80 \circ \mathrm{C}$ until RNA isolation. For ion analysis roots and leaves samples were collected in three pools of three plants each at 120 hours.

\section{Ion analysis}

To determine the $\mathrm{Na}^{+}$and $\mathrm{B}$ content, leaves and roots samples were dried at $60 \stackrel{\circ}{\circ}$ and finely ground. Then they were dry-ashed in a muffle furnace at 550 ㅇ C for 4 hours and treated with $\mathrm{HCl}(2 \mathrm{~N})$. The $\mathrm{Na}^{+}$content was quantified by flame photometry (model PFP7, Jenway, Staffordshire, United Kingdom) and $B$ by molecular absorption spectrometry (model UV-2100, Unico, New Jersey, USA). Ion content was measured in pools of leaves and roots of three plants, with three biological replicates and three technical replicates.

\section{RNA isolation and CDNA synthesis}

Total RNA from leaf and root tissues was isolated using the Trizol ${ }^{\circledR}$ reagent (Invitrogen) according to procedures specified by the manufacturer. The extracted RNA was resuspended in $20 \mu \mathrm{l}$ of RNase-free water and stored at $-80^{\circ} \mathrm{C}$. Integrity was verified by electrophoresis in $1 \%$ agarose gels. RNA was purified with the RNeasy ${ }^{\circledR}$ MinElute ${ }^{\mathrm{TM}}$ Cleanup Kit (QIAGEN) according to procedures specified by the manufacturer. RNA concentration was calculated using a Biophotometer (Eppendorf). Then $1 \mu \mathrm{g}$ of RNA was treated with DNase I in a final volume of $10 \mu \mathrm{l}$ and incubated at $37^{\circ} \mathrm{C}$ for 1 hour. The reaction was stopped by adding $1 \mu$ EDTA $(25 \mathrm{mM})$ at $65^{\circ} \mathrm{C}$ for 5 minutes.

The synthesis of the first strand of cDNA was performed as follows: $1 \mu \mathrm{g}$ RNA treated with DNase I (Invitrogen), $3 \mu \mathrm{l}$ oligo dT $(10 \mathrm{pmol} / \mu \mathrm{l})$, and $3 \mu \mathrm{l}$ dNTPs $(2.5 \mathrm{mM})$ were combined in a final volume of $17 \mu$, which was incubated at $65^{\circ} \mathrm{C}$ for 5 minutes. Then $8 \mu \mathrm{l}$ of $5 x$ First Strand Buffer, $2 \mu \mathrm{l}$ $0.1 \mathrm{M}$ DTT, $1 \mu \mathrm{l}$ RNasaOut (Invitrogen) and $1 \mathrm{ml}$ SuperScript ${ }^{\mathrm{TM}}$ III RT (Invitrogen) were added in a final volume of $40 \mu$ l. Reverse transcription was performed in a thermocycler model NYX TECHNIK Amplitronyx ${ }^{\mathrm{TM}} 6$, using the following program: $15^{\circ} \mathrm{C}$ for 10 minutes, $25^{\circ} \mathrm{C}$ for $16 \mathrm{~min}$, $42^{\circ} \mathrm{C}$ for $60 \mathrm{~min}, 70^{\circ} \mathrm{C}$ for $10 \mathrm{~min}$ and $4^{\circ} \mathrm{C}$ final hold. The tubes were stored at $-20^{\circ} \mathrm{C}$ until further use.

\section{Semi-quantitative and real-time PCR (qPCR) analysis}

For semi-quantitative RT-PCR, $2 \mu$ of the first-strand CDNA reaction served as template in a PCR reaction that used specific primers (Table 1 ) in a final volume of $20 \mu$ l. Optimal cycle number in the linear range for each target gene was determined empirically by performing PCR reactions for different numbers of cycles (Marone et al., 2001). The amplifications were performed under the following conditions: an initial denaturation at $95^{\circ} \mathrm{C}$ for $5 \mathrm{~min}$, then $94^{\circ} \mathrm{C}$ for $30 \mathrm{sec}, 56^{\circ} \mathrm{C}$ for $30 \mathrm{sec}$ and $72^{\circ} \mathrm{C}$ for $30 \mathrm{sec}$. The constitutive expressed gene Actin1 (ACT1) was used as an internal control. The PCR products were separated on $1.5 \%$ agarose gels.

For qPCR analysis, the genes of interest were amplified using the Maxima SYBR Green/ ROX qPCR Master Mix (2x) (Thermo Scientific) and real-time PCR was performed in an Eco Real-Time System (Illumina). All gene specific primers used for the qPCR analysis were designed using the Integrated DNA Technologies online PrimeTime qPCR assay design tool (http://www.idtdna.com/Scitools/Applications/RealTimePCR /) (Table 1). Maize Cullin (CUL) gene was used as housekeeping gene for normalization (Manoli et al., 2012). The reaction conditions used were: $95^{\circ} \mathrm{C}$ for $10 \mathrm{~min}, 40$ cycles of $95^{\circ} \mathrm{C}$ for $15 \mathrm{sec}, 60^{\circ} \mathrm{C}$ for $15 \mathrm{sec}, 72^{\circ} \mathrm{C}$ for $15 \mathrm{sec}$, and an analysis of dissociation or melting of 55 to $95^{\circ} \mathrm{C}$ with a temperature increase of $0.3^{\circ} \mathrm{C} \mathrm{sec}^{-1}$.

The efficiency of the PCR reaction in real time was calculated for each of the transcripts used by using 6 serial dilutions of cDNA, with an initial concentration of $32 \mathrm{ng}$ and a dilution factor of 1:2. The efficiency $(E)$ was determined with the following formula: $E=10^{-\frac{1}{\text { slope }}}$

\section{Quantification and data analysis}

Considering the efficiency of about $100 \%$ in all reactions, the quantification method that was used to measure the relative changes in genes expression was $2^{-\Delta \Delta \mathrm{Ct}}$, based on Livak and Schmittgen, (2001). Three biological replicates were performed, and three technical replicates for each biological replicate. A t-test analysis was performed $(P \leq 0.05)$ to analyze the differentially expressed genes in the leaves and roots tissues and control samples.

\section{Conclusion}

The results in this study indicate that a combined salt and B stress causes physiological parameter changes and more severe damage in commercial hybrid than in Lluteño maize, indicating that this landrace behaves as a plant tolerant to these stresses. Also, the regulation of stress-related genes under combined stress was different than for individual stresses. The ability of Lluteño maize to survive and thrive in soil with high salinity and B concentration is probably based on decreased membrane water permeability. This prevents salt and $B$ uptake from the roots by down-regulation of BOR1, BOR2 transporters and PIP1;2 aquaporin. It also restricts $B$ movement and accumulation in aerial parts through down-regulation of BOR1 and BOR2 transporters, increasing water transport mediated by up-regulation of the PIP1;2 in leaves. It allows cellular water conservation and the retrieval of $\mathrm{Na}^{+}$from xylem through up-regulation of HKT1;1 transporters in roots and leaves. These results give us only partial knowledge about of the role of some tolerance genes in acquiring salinity and $B$ stress tolerance in Lluteño maize, thus the characterization of all tolerance genes is necessary.

\section{Acknowledgments}

This research was supported by FONDECYT 11100492 and Convenio de Desempeño en Educación Superior Regional UTA-1401.

\section{References}

Apse MP, Aharon GS, Snedden WA, Blumwald E (1999) Salt tolerance conferred by overexpression of a vacuolar $\mathrm{Na} / \mathrm{H}$ Antiport in Arabidopsis. Science. 285 :1256-1258. 
Aroca R, Ferrante A, Vernieri P, Chrispeels MJ (2006) Drought, abscisic acid and transpiration rate effects on the regulation of PIP aquaporin gene expression and abundance in Phaseolus vulgaris plants. Ann Bot-London. 98: 1301-1310.

Bañuelos GS, Ajwa HA, Caceres L, Dyer D (1999) Germination responses and boron accumulation in germplasm from Chile and the United States grown with boron-enriched water. Ecotox Environ Safe. 43: 62-67.

Barragan V, Leidi EO, Andres Z, Rubio L, De Luca A, Fernandez JA, Cubero B, Pardo JM (2012) Ion exchangers NHX1 and NHX2 mediate active potassium uptake into vacuoles to regulate cell turgor and stomatal function in Arabidopsis. Plant Cell. 24: 1127-1142.

Bastías El, González-Moro MB, González-Murua C (2004) Zea mays L. amylacea from the Lluta valley (Arica-Chile) tolerates salinity stress when high levels of boron are available. Plant Soil. 267: 73-84.

Camacho-Cristóbal JJ, Rexach J, González-Fontes A (2008) Boron in plants: deficiency and toxicity. J Integr Plant Biol. 50: 1247-1255.

Colmenero-Flores JM, Rosales MA (2014) Interaction between salt and heat stress: when two wrongs make a right. Plant Cell Environ. 37: 1042-1045.

Dordas C, Chrispeels MJ, Brown PH (2001) Permeability and channel-mediated transport of boric acid across membrane vesicles isolated from squash roots. Plant Physiol. 124: 1349-1362.

Eraslan F, Inal A, Savasturk O, Gunes A (2007) Changes in antioxidative system and membrane damage of lettuce in response to salinity and boron toxicity. Sci HorticAmsterdam. 114: 5-10.

Fortmeier R, Schubert S (1995) Salt tolerance of maize (Zea mays L.): the role of sodium exclusion. Plant Cell Environ. 18: 1041-1047.

Fuentes F, Subiabre H (2009) Recursos forrajeros para la alimentación del ganado enel valle de Lluta). In: Tapia $F$. (ed.) Estudio básico: Investigación silvo-agropecuaria de innovación de la I Región. Santiago, Chile. Instituto de Investigaciones Agropecuarias. Boletín INIA. N 197.

Hajibagheri MA, Harvey DMR, Flowers TJ (1987) Quntitative ion distribution within root cells of salt-sensitive and salttolerant maize varieties. New Phytol. 105: 367-379.

Hanin M, Ebel Ch, Ngom M, Laplaze L, Masmoudi K (2016) New insights on plant salt tolerance mechanisms and their potential use for breeding. Front Plant Sci. 7: 1787.

Hove RM, Ziemann M, Bhave M (2015) Identification and expression enalysis of the barley (Hordeum vulgare L.) aquaporin gene family. Plos One. 10: e0128025.

Jang JY, Kim DG, Kim YO, Kim JS, Kang H (2004) An expression analysis of a gene family encoding plasma membrane aquaporins in response to abiotic stresses in Arabidopsis thaliana. Plant Mol Biol. 54: 713-725.

Jin H, Dong D, Yang Q, Zhu D (2016) Salt-responsive transcriptome profiling of Suaeda glauca via RNA sequencing. Plos One. 11: e0150504.

Kumar K, Mosa KA, Chhikara S, Musante C, White JC, Dhankher OP (2014) Two rice plasma membrane intrinsic proteins, OsPIP2;4 and OsPIP2;7, are involved in transport and providing tolerance to boron toxicity. Planta. 239: 187-198.
Liu M, Wang T-Z, Zhang W-H (2015) Sodium extrusion associated with enhanced expression of SOS1 underlies different salt tolerance between Medicago falcata and Medicago truncatula seedlings. Environ Exp Bot. 110: 4655.

Livak KJ, Schmittgen TD (2001) Analysis of relative gene expression data using real-time quantitative PCR and the 2(-Delta Delta C(T)) Method. Methods. 25: 402-408.

Manoli A, Sturaro A, Trevisan S, Quaggiotti S, Nonis A (2012) Evaluation of candidate reference genes for $\mathrm{qPCR}$ in maize. J Plant Physiol. 169: 807-815.

Marone M, Mozzetti S, De Ritis D, Pierelli L, Scambia G (2001) Semiquantitative RT-PCR analysis to assess the expression levels of multiple transcripts from the same sample. Biol Proced Online. 3: 19-25.

Mäser P, Eckelman B, Vaidyanathan R, Horie T, Fairbairn DJ, Kubo M, Yamagami M, Yamaguchi K, Nishimura M, Uozumi N, Robertson W, Sussman MR, Schroeder JI (2002) Altered shoot/root $\mathrm{Na}^{+}$distribution and bifurcating salt sensitivity in Arabidopsis by genetic disruption of the $\mathrm{Na}^{+}$transporter AtHKT1. FEBS Lett. 531: 157-161.

Maurel C, Verdoucq L, Luu DT, Santoni V (2008) Plant aquaporins: membrane channels with multiple integrated functions. Annu Rev Plant Biol. 59: 595-624.

Mittler R (2006) Abiotic stress, the field environment and stress combination. Trends Plant Sci. 11: 15-19.

Miwa K, Wakuta S, Takada S, Ide K, Takano J, Naito S, Omori H, Matsunaga T, Fujiwara T (2013) Roles of BOR2, a boron exporter, in cross linking of rhamnogalacturonan II and root elongation under boron limitation in Arabidopsis. Plant Physiol. 163: 1699-1709.

Mohamed AKSH, Qayyum MF, Shahzad AN, Gul M, Wakeel A (2016) Interactive effect of boron and salinity on growth, physiological and biochemical attributes of wheat (Triticum aestivum). Int J Agric Biol. 18: 238-244.

Moles TM, Pompeiano A, Huarancca Reyes T, Scartazza A, Guglielminetti $L$ (2016) The efficient physiological strategy of a tomato landrace in response to short-term salinity stress. Plant Physiol Bioch. 109: 262-272.

Munns R, Tester M (2008) Mechanisms of salinity tolerance. Annu Rev Plant Biol. 59: 651-681.

Nable RO, Bañuelos GS, Paull JG (1997) Boron toxicity. Plant Soil. 193: 181-198.

Ouziad F, Wilde $P$, Schmelzer $E$, Hildebrandt $U$, Bothe $H$ (2006) Analysis of expression of aquaporins and $\mathrm{Na}^{+} / \mathrm{H}^{+}$ transporters in tomato colonized by arbuscular mycorrhizal fungi and affected by salt stress. Environ Exp Bot. 57: 177-186.

Pawłowicz I, Rapacz M, Perlikowski D, Gondek K, Kosmala A (2017) Abiotic stresses influence the transcript abundance of PIP and TIP aquaporins in Festuca species. J Appl Genet. 58: 421-435.

Polsia Princi M, Lupini A, Araniti F, Longo C, Mauceri A, Sunseri F, Abenavoli MR (2016) Boron toxicity and tolerance in plants: recent advances and future perspectives. In: Ahmad P (ed) Plant Metal Interaction: Emerging Remediation Techniques. Elsevier, Amsterdam.

Porcel R, Aroca R, Azcón R, Ruiz-Lozano JM (2006) PIP aquaporin gene expression in arbuscular mycorrhizal Glycine max and Lactuca sativa plants in relation to drought stress tolerance. Plant Mol Biol. 60: 389-404. 
Rahman MA, Thomson MJ, Shah-E-Alam M, de Ocampo M, Egdane J, Ismail AM (2016) Exploring novel genetic sources of salinity tolerance in rice through molecular and physiological characterization. Ann Bot-London. 117: 1083-1097.

Rampino P, Pataleo S, Gerardi C, Mita G, Perrota C (2006) Drought stress response in wheat: physiological and molecular analysis of resistant and sensitive genotypes. Plant Cell Environ. 29: 2143-2152.

Ren Z, Liu Y, Kang D, Fan K, Wang C, Wang G, Liu Y (2015) Two alternative splicing variants of maize HKT1;1 confer salt tolerance in transgenic tobacco plants. Plant Cell Tiss Org. 123: 569-578.

Rivero RM, Mestre TC, Mittler R, Rubio F, Garcia-Sanchez F, Martinez V (2014) The combined effect of salinity and heat reveals a specific physiological, biochemical and molecular response in tomato plants. Plant Cell Environ. 37: 10591073.

Rodriguez HG, Roberts J, Jordan WR, Drew MC (1997) Growth, water relations, and accumulation of organic and inorganic solutes in roots of maize seedlings during salt stress. Plant Physiol. 113: 881-893.

Rubio F, Gassmann W, Schroeder JI (1995) Sodium-driven potassium uptake by the plant potassium transporter HKT1 and mutations conferring salt tolerance. Science. 270: 1660-1663.

Ruiz KB, Aloisi I, Del Duca S, Canelo V, Torrigiani, Silva H, Biondi S (2016) Salares versus coastal ecotypes of quinoa: Salinity responses in Chilean landraces from contrasting habitats. Plant Physiol Bioch. 101: 1-13.

Ruiz, O, Beltrán R, Salvador F, Rubio H, Grado A, Castillo Y (2006) Valor nutritivo y rendimiento forrajero de híbridos de maíz para ensilaje. Rev Cubana Cienc Agríc. 40: 91-96.

Sandhu D, Cornacchione MV, Ferreira JFS, Suarez DL (2017) Variable salinity responses of 12 alfalfa genotypes and comparative expression analyses of salt-response genes. Sci Rep-UK. 7: 42958.

Sathee L, Sairam RK, Chinnusamy V, Jha SK (2015) Differential transcript abundance of salt overly sensitive (SOS) pathway genes is a determinant of salinity stress tolerance of wheat. Acta Physiol Plant. 37: 169.

Sun W, Xu X, Zhu H, Liu A, Liu L, Li J, Hua X (2010) Comparative transcriptomic profiling of a salt-tolerant wild tomato species and a salt-sensitive tomato cultivar. Plant Cell Physiol. 51: 997-1006.

Sutton T, Baumann U, Hayes J, Collins NC, Shi BJ, Schnurbusch T, Hay A, Mayo G, Pallotta M, Tester M, Langridge $P$ (2007) Boron-toxicity tolerance in barley arising from efflux transporter amplification. Science. 318 1446-1449.

Suzuki N, Rivero RM, Shulaev V, Blumwald E, Mittler R (2014) Abiotic and biotic stress combinations. New Phytol. 203: 32-43.

Takano J, Miwa K, Yuan L, von Wiren N, Fujiwara T (2005) Endocytosis and degradation of BOR1, a boron transporter of Arabidopsis thaliana, regulated by boron availability. $\mathrm{P}$ Natl Acad Sci USA. 102: 12276-12281.

Takano J, Wada M, Ludewig U, Schaaf G, von Wiren N, Fujiwara T (2006) The Arabidopsis major intrinsic protein NIP5;1 is essential for efficient boron uptake and plant development under boron limitation. Plant Cell. 18: 14981509.

Tanaka M, Fujiwara T (2008) Physiological roles and transport mechanisms of boron: perspectives from plants. Pflug Arch Eur J Phy. 456: 671-677.

Tapia F, Vega B (2009) Tipologías de productores en el valle de Lluta. In: Tapia F. (ed.) Estudio basico: Investigacion silvo-agropecuaria de innovacion de la I Region. Santiago, Chile. Instituto de Investigaciones Agropecuarias. Boletin INIA. N¹97.

Tester M, Davenport $\mathrm{R}$ (2003) $\mathrm{Na}^{+}$tolerance and $\mathrm{Na}^{+}$ transport in higher plants. Ann Bot-London. 91: 503-527.

Torres A, Acevedo E (2008) The salinity problem of the water and soil resources in Lluta and Azapa valleys in northern Chile. Idesia. 26: 31-44.

Tuteja N (2007) Mechanisms of high salinity tolerance in plants. Methods in Enzymol. 428: 419-438.

Wang H, Miyazaki S, Kawai K, Deyholos M, Galbraith DW, Bohnert HJ (2003) Temporal progression of gene expression responses to salt shock in maize roots. Plant Mol Biol. 52: 873-891.

Yoshinari A, Kasai K, Fujiwara T, Naito S, Takano J (2012) Polar localization and endocytic degradation of a boron transporter, BOR1, is dependent on specific tyrosine residues. Plant Signal Behav. 7:.46-49.

Yousfi S, Márquez AJ, Betti M, Araus JL, Serret MD (2016) Gene expression and physiological responses to salinity and water stress of contrasting durum wheat genotypes. J Integr Plant Biol. 58: 48-66.

Zhu C, Schraut D, Hartung W, Schäffner AR (2005) Differential responses of maize MIP genes to salt stress and ABA. J Exp Bot. 56: 2971-2981.

Zhu JK (2003) Regulation of ion homeostasis under salt stress. Curr Opin Plant Biol. 6: 441-445. 